\title{
Ultrasound Synthesis of Benzimidazolo-1,3,5-triazine Derivatives and their Anti-histamine and Anti-diabetic Activities
}

\author{
SUHAILAH S. ALJAMEEL ${ }^{1}$, HOUDA M. FATAFTAH ${ }^{1}$, SOHEIR N. ABD EL-RAHMAN², \\ ASMA, M. ELSHARIF ${ }^{1}$, A. HAFIANE ${ }^{3}$ and MADIHA KAMOUN ${ }^{1 *}$ \\ ${ }^{1}$ Department of Chemistry, College of Science, Imam Abdulrahman Bin Faisal University, \\ P.O. Box 1982, Dammam 31441, Saudi Arabia. \\ ${ }^{1}$ Basic and Applied Scientific Research Center, Imam Abdulrahman Bin Faisal University, \\ P.O. Box 1982, 31441, Dammam, Saudi Arabia. \\ ${ }^{2}$ Crops Technology Research Department, Food Technology Research Institute, \\ Agricultural Research Center, Giza, Egypt. \\ ${ }^{3}$ LEMBE, CERTE Borj Cedria, Soliman-8027, Tunisia. \\ ${ }^{*}$ Corresponding author E-mail:mokamoun@iau.edu.sa \\ http://dx.doi.org/10.13005/ojc/350417
}

(Received: May 22, 2019; Accepted: July 01, 2019)

\begin{abstract}
The present work aims to evaluate the anti-diabetic and anti-histamine activity of the synthesized benzimidazolo-1,3,5- triazine derivatives. These newly products have been synthesized under ultrasound irradiation with good yields and their structures were established by spectral data. The amylase inhibition assay and diclorofenac were used to evaluate the antidiabetic and antihistamine of all synthesized derivatives, respectively. It was shown that compounds $\mathbf{3 c}$ and $\mathbf{3 e}$ give the best of inhibition results of the amylase enzyme with respect to 2-aminobenzimidazole and other derivatives at a concentration of $1000 \mu \mathrm{g} / \mathrm{L}, \mathrm{IC}_{50}=59.4$ and 52.1, respectively. Furthermore, compounds $3 \mathbf{e}$, 3f, 3d, and $\mathbf{3 a}$ give highly significant inhibition activity against histamine at various concentrations, $\mathrm{IC}_{50}=25.6,29.4,101.9,121.6$, respectively, than compound 3c, 3b, and 2-aminobenzimidazole.
\end{abstract}

Keywords: 2-aminobenzimidazole, Anti-histamine activity, Benzimidazolo-1,3,5- triazine.

\section{INTRODUCTION}

Heterocyclic compounds are to be the important family of organic compounds used in the drug discovery process. They have been tremendously used in many fields of science, such as medicinal, pharmaceutical chemistry and biochemistry. The presence of heteroatoms in their structure is responsible for biological activity. The heterocyclic compounds are present in many natural products such as antibiotics vitamins, hormones etc. Also, they are known for their wide range of applications on pharmacology as an analgesic ${ }^{1}$, antibacterial ${ }^{2}$, anticonvulsant ${ }^{3,4}$, antifungal $^{5}$, antihistaminic ${ }^{6}$, anti-inflammatory ${ }^{7}$, anticancer $^{8}$, antihypertensive, antineuropathic ${ }^{9}$ etc.

This is an Open Access article licensed under a Creative Commons license: Attribution 4.0 International (CC- BY). Published by Oriental Scientific Publishing Company @ 2018

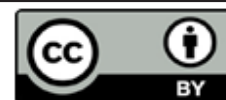


A benzimidazole moiety represents an important pharmacophore of selection for establishing anti-inflammatory, analgesic molecules and has a privileged structure in medicinal chemistry ${ }^{10}$. Substituted benzimidazole at the positions 1 and 2 shows a powerful antioxidant activity ${ }^{11-13}$. Heterocyclic compounds containing fluorine afford interesting biological activities compared to their non-fluorinated counterparts ${ }^{14-19}$. The synthesis from iminoester has attracted considerable attention, essentially in the preparation of heterocyclic compounds ${ }^{20-22}$. Allergy with its various manifestations that affect the humankind is one of the most widespread diseases, various types of mast cell activation reactions and type I hypersensitivity reactions ${ }^{23}$, which is the main effector cell in the release of histamine by activated mast cells and allergic inflammation, may also be mentioned ${ }^{24}$. The substituted triazines have fascinating biological activities such as anti-inflammatory, anti-cancer and trypanocidal activities ${ }^{25}$. In addition, 1, 2, 4-1, 3, 5-1, 2, 3-triazines derivatives are considered as bioactive molecules with a diversity of biological activities like analgesic, anti-inflammatory, antihistaminic and prostaglandin inhibition properties ${ }^{26}$.

Diabetes mellitus is currently one of the most prevalent and ever-increasing diseases leading to the risk of premature death and the development of various diseases, particularly cardiovascular diseases, kidney failure, cognitive decline, depression ${ }^{27}$. New 1, 3, 5-triazine derivatives synthesized from Metformin, magnolol and berberine showed excellent activity as anti-insulin resistance and anti-inflammation ${ }^{28}$. In the past the no-steroidal anti-inflammatory drugs (NSAIDs) has been used successfully worldwide by millions of patients for inflammation and pain alleviation and continues to be used daily till now. Nevertheless, the relationship between the toxicity of gastrointestinal (GI) and NSAIDs is an important socioeconomic and medical problem ${ }^{29}$. Considerable attention has been focused on the synthesis of heterocyclic compounds using ultrasound assisted reaction producing short times and excellent yields of product. Moreover, many researchers study the effect of triazine ring as antimicrobial antioxidant and anti-cancer. Therefore, in this present work, we shall optimize the synthesis of various new $p$-halogeno phenyl benzimidazolo1,3,5-triazine derivatives by using a novel method of synthesis under ultrasound assisted reaction and then, we investigate their anti-inflammatory and anti-diabetic activity.

\section{MATERIALS AND METHODS}

The infra-red spectra were recorded a Shimadzu IR AFFINITY-FT-IR spectrometer. NMR spectra $\left({ }^{1} \mathrm{H},{ }^{13} \mathrm{C},{ }^{19} \mathrm{~F}\right)$ were registered on a Bruker AC $(300 \mathrm{MHz})\left(75.47 \mathrm{MHz}\right.$ for ${ }^{13} \mathrm{C}, 282.39 \mathrm{MHz}$ for $\left.{ }^{19} \mathrm{~F}\right)$. TMS ( $\delta \mathrm{ppm}$ ) (for ${ }^{13} \mathrm{C}$ and ${ }^{1} \mathrm{H}$ NMR) and external standard (for ${ }^{19} \mathrm{~F}$ NMR) $\mathrm{C}_{6} \mathrm{~F}_{6}$. Melting points were determined with SPM 30. The elemental analysis was carried in the analysis center of the Paris VI University. The mass spectra were recorded Shimadzu LC-MS 8040 spectrometer.

\section{General procedure for the preparation of benzimidazolo-1, 3, 5-triazine derivatives 3a-f}

The preparation of compound 2 reached according to the procedure mention in the literature ${ }^{30}$. The benzimidazolo-1,3,5-triazine derivatives 3a-f were synthesized as follows.

$5 \mathrm{mmol}$ of imidate 2 and $5 \mathrm{mmol}$ of differently substituted $p$-halogeno phenyl isothiocyanate were mixed in $2 \mathrm{ml}$ of dry THF. The mixture was then carried under ultrasound irradiation for 2 h 40 $\left(60 \mathrm{kHz}, 45^{\circ} \mathrm{C}\right)$. The solid so obtained is rinsed with ether and then filtered under vacuum. The obtained product was recrystallized from methanol.

3-(phenyl)-2-ethyl [1, 2-a] benzimidazolo-1, 3, 5-triazin-4-thione (3b):Yield $=65 \%$; (m.p.) $178^{\circ} \mathrm{C}$. ${ }^{1} \mathrm{H} \mathrm{NMR}\left(\mathrm{CDCl}_{3}\right) \delta: 1.30(\mathrm{t}, 3 \mathrm{H}, \mathrm{J}=7.3 \mathrm{~Hz}) ; 2.46$ (q, $2 \mathrm{H}, \mathrm{J}=7.3 \mathrm{~Hz}) ; 7.26-9.07(\mathrm{~m}, 8 \mathrm{H}) .{ }^{13} \mathrm{C} \mathrm{NMR}\left(\mathrm{CDCl}_{3}\right)$

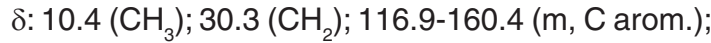
$160.4(\mathrm{C}=\mathrm{N}) ; 172.6(\mathrm{C}=\mathrm{S})$. IR v: $1615 \mathrm{~cm}^{-1}(\mathrm{C}=\mathrm{N})$. LCMS m/z: $307(\mathrm{M}+\mathrm{H})^{+}$.

3-(phenyl)-2-methyl [1, 2-a] benzimidazolo-1, 3, 5-triazin-4-thione (3a): Yield $=70 \%$; (m.p.) $197^{\circ} \mathrm{C}$. ${ }^{1} \mathrm{H}$ NMR $\left(\mathrm{CDCl}_{3}\right) \delta: 2.31(\mathrm{~s}, 3 \mathrm{H}) ; 7.26-9(\mathrm{~m}, 9 \mathrm{H})$. ${ }^{13} \mathrm{C} \mathrm{NMR}\left(\mathrm{CDCl}_{3}\right)$ 8: $25.3\left(\mathrm{CH}_{3}\right) ; 116.8-145.7(\mathrm{~m}, \mathrm{C}$ arom.); $156.3(\mathrm{C}=\mathrm{N}) ; 172.4(\mathrm{C}=\mathrm{S})$. IR v: $1615 \mathrm{~cm}^{-1}$ $(\mathrm{C}=\mathrm{N})$. LCMS m/z: $293(\mathrm{M}+\mathrm{H})^{+}$.

3-(4-fluorophenyl) -2-ethyl [1, 2-a] benzimidazolo -1, 3, 5-triazin-4-thione (3c): Yield = $80 \%$; (m.p.) $195^{\circ} \mathrm{C} .{ }^{1} \mathrm{H}$ NMR $\left(\mathrm{CDCl}_{3}\right) \delta: 1.30$ (t, 3H, $\mathrm{J}=7 \mathrm{~Hz}) ; 2.46(\mathrm{q}, 2 \mathrm{H}, \mathrm{J}=7 \mathrm{~Hz}) ; 7.26-9.06(\mathrm{~m}, 8 \mathrm{H})$. ${ }^{13} \mathrm{C}$ NMR $\left(\mathrm{CDCl}_{3}\right)$ 8: $10.4\left(\mathrm{CH}_{3}\right) ; 30.4\left(\mathrm{CH}_{2}\right) ; 116$. 
8-162.1 (m, $\mathrm{C}_{6} \mathrm{H}_{4} \mathrm{~F}+$ Carom); 164.06(C=N); 172.5 $(\mathrm{C}=\mathrm{S}) .{ }^{19} \mathrm{~F} \mathrm{NMR}\left(\mathrm{CDCl}_{3}\right) \delta: 52.27(\mathrm{~m}, 1 \mathrm{~F}, 3 \mathrm{JF}-\mathrm{H}=5.64$ Hz). IR v: $1599 \mathrm{~cm}^{-1}(\mathrm{C}=\mathrm{N})$. LCMS m/z: $323(\mathrm{M}-\mathrm{H})^{+}$.

3-(4-fluorophenyl)-2-methyl [1, 2-a] benzimidazolo-1, 3, 5-triazin-4-thione (3d):Yield = 75\%; (m.p.) $198^{\circ} \mathrm{C} .{ }^{1} \mathrm{H} \mathrm{NMR}\left(\mathrm{CDCl}_{3}\right)$ $\delta: 2.33(\mathrm{~s}, 3 \mathrm{H}) ; 7.26-9.01$ (m, 8H). ${ }^{13} \mathrm{C} \mathrm{NMR}\left(\mathrm{CDCl}_{3}\right) \delta: 25.3\left(\mathrm{CH}_{3}\right) ; 116.8-145.7$ (m, $\mathrm{C}_{6} \mathrm{H}_{\mathrm{F}}+\mathrm{C}$ arom.); $156.3(\mathrm{C}=\mathrm{N}) ; 172.1(\mathrm{C}=\mathrm{S}) .{ }^{19} \mathrm{~F}$ $\operatorname{NMR}\left(\mathrm{CDCl}_{3}\right) \delta: 52.48\left(\mathrm{~m}, 1 \mathrm{~F},{ }^{3} \mathrm{~J}_{\mathrm{F}-\mathrm{H}}=5.64 \mathrm{~Hz}\right)$. IR v: $1615 \mathrm{~cm}^{-1}(\mathrm{C}=\mathrm{N})$. Elemental analysis: calculated for $\mathrm{C}_{16} \mathrm{H}_{11} \mathrm{FN}_{4} \mathrm{~S}$ : C, 61.99; H, 3. 58; N, 18.07. Found: C, 61.83; H, 3.52; N, 17.86. LCMS m/z: 311(M+H)

3-(4-chlorophenyl) -2-ethyl [1, 2-a] benzimidazolo -1, 3, 5-triazin-4-thione (3e): Yield $=92 \% ;$ (m.p.) $199^{\circ} \mathrm{C} .{ }^{1} \mathrm{H}$ NMR (DMSO-d 6 ) $\delta: 1.17$ (t, 3H, J = $7 \mathrm{~Hz}) ; 2.49$ (q, 2H, J = 7 Hz); 7.44-9.05 (m, 8H). $\left.{ }^{13} \mathrm{C} \mathrm{NMR} \mathrm{(DMSO-d}\right)$ ) $: 10.3\left(\mathrm{CH}_{3}\right) ; 30.3\left(\mathrm{CH}_{2}\right)$; 116.8-164 (m, $\left.\mathrm{C}_{6} \mathrm{H}_{4} \mathrm{~F}+\mathrm{Carom}\right) ; 156(\mathrm{C}=\mathrm{N}) ; 172.5$ $(\mathrm{C}=\mathrm{S})$. LCMS m/z: $341(\mathrm{M}+\mathrm{H})^{+}$.

3-(4-clorophenyl)-2-methyl [1, 2-a] benzimidazolo-1, 3, 5-triazin-4-thione (3f): Yield $=85 \%$; (m.p.) $163^{\circ} \mathrm{C}$. ${ }^{1} \mathrm{H}$ NMR (DMSO-d $\left.{ }_{6}\right) \delta: 2.32$ (s, 3H); 7.26-9 (m, 8H). ${ }^{13} \mathrm{C}$ NMR (DMSO-d $\left.\mathrm{d}_{6}\right) \delta: 25.4$ $\left(\mathrm{CH}_{3}\right) ; 116.8-164.1$ (m, $\mathrm{C}_{6} \mathrm{H}_{4} \mathrm{Cl}+\mathrm{C}$ arom.); 156.74 $(\mathrm{C}=\mathrm{N}) ; 172.52(\mathrm{C}=\mathrm{S})$. LCMS m/z: $325(\mathrm{M}-\mathrm{H})^{+}$.

\section{Assay of the inhibition of $\alpha$-amylase}

Colorimetric microplate assay was used to determine the inhibitory of $\alpha$-amylase activity according to a well-established method ${ }^{31}$. A 96well plate was used to mix the enzyme reaction consisted of porcine pancreatic $\alpha$-amylase (1.25 $\mathrm{mM}$ ) (p-nitrophenyl- $\alpha$-D-maltopentaoside (PNPG-5), (VI-B, $\geq 10$ units/mg (solid) (4mg), and samples ( $1 \mathrm{mg}$ ). Then, the enzyme reaction was monitored by using the reader of the microplate at wavelength of $405 \mathrm{~nm}$. The inhibition of $\alpha$-amylase percentage was calculated by the following equation:

$\%$ inhibition $=($ Abs $(C)-$ Abs $(S)) \times 100$

Where Abs (C) and Abs (S) are absorbance of control and sample, respectively.

The $\alpha$-amylase inhibitor concentration was defined as the value of $\mathrm{IC}_{50}$ which inhibit $50 \%$ of the activity of the enzyme within the testing conditions.

\section{Assays of anti-inflammatory (In vitro) Assay of histamine release}

The samples effect on the histamine release was studied by monocytes of U937 human. A 96-well cell culture plate (Corning Life Sciences, Lowell, MA, USA)was used to plate about 50,000 U937 cells, then treated with samples ( 7.81 to $1000 \mathrm{ng} \mathrm{m} \mathrm{sec}^{-1}$ ) at various concentrations, for one hour in absence or presence of PMA (Phorbol Myristate Acetate) (20 nM) (Sigma-Aldrich, St. Luis, MO, USA). The supernatants of the cell culture were collected from both treated cultures and untreated control and clarified for $5 \mathrm{~min}$ at $4^{\circ} \mathrm{C}$ and $10,000 \mathrm{~g}$ and used a commercially available EIA kit (SPI-Bio, France) to assess the histamine released ${ }^{32}$.

\section{RESULTS AND DISCUSSION}

The desired fused heterocyclic compounds (3a-f) were synthesized as shown in Scheme 1. The 2-aminobenzimidazole were purchased from Sigma Aldrich and the N-(2-benzimidazolyl) imidates 2a-b were prepared, by the treatment of 2-aminobenzimidazole 1 with an excess of orthoester, in the presence of acetic acid as catalyst under reflux for 48 hours. Treatment of compound 2 with substituted isothiocyanate in the presence of THF under ultrasound irradiation $(60 \mathrm{kHz})$ forming an intermediate A Scheme 2, non-isolated, followed by an intramolecular cyclization reaction to afford phenylbenzimidazolo-1,3,5-triazin-4-thione 3a-b, p-fluorophenyl benzimidazolo-1,3,5-triazin-4-thione 3c-d, and p-chlorophenyl benzimidazolo-1,3,5-triazin-4thione $3 \mathrm{e}-\mathrm{f}$ in good yields. Compared with conventional methods using THF at room temperature for 7 days, ultrasound procedure has several advantages such as short time of the reaction and higher yields.

All the products are newly synthesized except phenylbenzimidazolo-triazin-4-thione (3a and $3 b)^{30}$. In our study, phenyl benzimidazolo-triazin-4thione 3a-b have been prepared to compare their biological activity, with the electron withdrawing group at phenyl nucleus, such as fluorine and chlorine atoms, introduced by isothiocyanate in the newly synthesized benzimidazolo-triazine derivatives. To our knowledge all synthesized products are biologically evaluated for the first time.

All newly synthesized products were characterized by various spectroscopy techniques. The structure of the isolated product was recognized by the use of MS, elemental analysis for $3 d$ and spectral datum. As an example, for the sample $3 \mathrm{c}$, the ${ }^{1} \mathrm{H}$ NMR spectrum revealed the disappear-rance of signal 
specific to the ethoxy group and the emergence of a singlet in 2.3 ppm due to the methyl proton.

Aromatic multiples in the region 7.5-9 introduced byisothiocyanateconfirms heterocyclization. Compounds 3a-f IR spectra showed characteristic absorption bands at $1615-1621 \mathrm{~cm}^{-1}$ relative to $\mathrm{C}=\mathrm{N}$ cyclic. The ${ }^{13} \mathrm{C}$ NMR exhibits all special signals of all carbon. Fluorine ${ }^{19} \mathrm{~F}$ NMR spectroscopy confirms this cyclization by the appearance of the signals attributable to the $\mathrm{R}_{f}$ motifs.

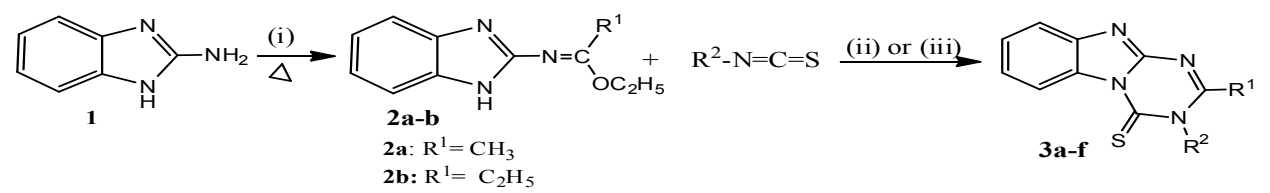

\begin{tabular}{ccccc}
\hline Compound 3a-f & $\mathrm{R}^{1}$ & $\mathrm{R}^{2}$ & Yield (\%) $45^{\circ} \mathrm{C}, 2 \mathrm{~h} 40$ & Yield (\%)7 days, $25^{\circ} \mathrm{C}$ \\
\hline 3a & $\mathrm{C}_{2} \mathrm{H}_{5}$ & $\mathrm{C}_{6} \mathrm{H}_{5}$ & 70 & 60 \\
$3 \mathrm{~b}$ & $\mathrm{CH}_{3}$ & $\mathrm{C}_{6} \mathrm{H}_{5}$ & 65 & 58 \\
$3 \mathrm{c}$ & $\mathrm{C}_{2} \mathrm{H}_{5}$ & $\mathrm{C}_{6} \mathrm{H}_{4} \mathrm{~F}$ & 80 & 75 \\
$3 \mathrm{~d}$ & $\mathrm{CH}_{3}$ & $\mathrm{C}_{6} \mathrm{H} 4 \mathrm{~F}$ & 75 & 65 \\
$3 \mathrm{e}$ & $\mathrm{C}_{2} \mathrm{H}_{5}$ & $\mathrm{C}_{6} \mathrm{H}_{4} \mathrm{Cl}$ & 92 & 80 \\
$3 f$ & $\mathrm{CH}_{3}$ & $\mathrm{C}_{6} \mathrm{H}_{4} \mathrm{Cl}$ & 85 & 70 \\
\hline
\end{tabular}

Scheme 1. Reagent and condition: (i) Excess of orthoester, acetic acid (ii) $\mathrm{R}^{2}-\mathrm{N}=\mathrm{C}=\mathrm{S}, \mathrm{THF}$ anhydrous $25^{\circ} \mathrm{C}, 7$ days (iii) $\mathrm{R}^{2}-\mathrm{N}=\mathrm{C}=\mathrm{S}$, THF anhydrous ultrasound, $2 \mathrm{~h} 40,45^{\circ} \mathrm{C}$

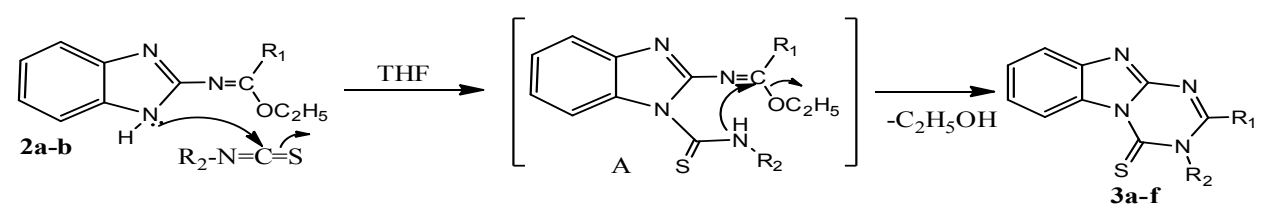

Scheme 2. Proposed Mechanism

$\alpha$-Amylase inhibitory by benzimidazolo-1,3,5triazine derivatives

The antidiabetic of substituted benzimidazolo1,3,5-triazine derivatives was carried out by using the assay of the colorimetric microplate (Table 1 and Fig.1). The inhibition was dramatically diminished by compound $3 \mathrm{a}(0 \%)$ compared to acarbose $(59.31 \%)$, 3c $(51.32 \%)$, 3d (46.38\%), 3e (54.31\%) and $3 f$ (42.84 \%) inhibition at $62.5 \mathrm{ug} / \mathrm{l}$ concentration. On the other hand, compound $3 \mathrm{c}$ and $3 \mathrm{e}$ give the best results of 73.15 and $71.34 \%$ on inhibition, at 1000 $\mu \mathrm{g} / \mathrm{l}$ concentration, $\mathrm{IC}_{50}=59.4$ and 52.1 , respectively than other derivatives. The result indicated that compound haveethyl group give a highly effect as antidiabetic in presence of electron withdrawing group at phenyl nucleus such as fluorine and chlorine atoms introduced by isothiocyanate. So, the inhibition of $\alpha$-amylase activity may be due to fluorine and chlorine atoms in the presence of ethyl group. Our results agree with those of Cao, et al., ${ }^{28}$ they noted a significant stimulatory effect of the synthesized triazines (compound 1-3) from berberine, magnolol and metformin, respectively, on the INS-1 cells insulin secretion. The insulin release was increased by $143 \%$ in the presence ofcompound 3 than to the model (A positive control is Metformin), while compound 2 and compound $\mathbf{1}$ was increased by $156 \%$ and $137 \%$, respectively. All compounds hadstimulatory effects on the INS-1 cells insulin secretion and anti-diabetic effect.

\section{Inhibition of histamine release by benzimidazolo- 1,3,5-triazine derivatives}

The results of the antihistamine activity of benzimidazole-1,3,5-triazine derivatives are shown in Table 2 and Fig. 2. Compound $\mathbf{3 e}$ and $\mathbf{3} \mathbf{f}$ gave the best results of inhibition of histamine release ((60.34, $57.19 \%)$ and $(82.35,73.21 \%))$ at 62.5 and $1000 \mathrm{ug} / \mathrm{L}$ concentration, $\mathrm{IC}_{50}=25.6,29.4$, respectively, than standard (ST), (00.00 and $32.11 \%)$ inhibition at 62.5 and $1000 \mu \mathrm{g} / \mathrm{I}$ concentration, respectively, $\mathrm{IC}_{50}=$ $1000<$ and other derivatives. Additionally, the results show that compounds $\mathbf{3 a}, \mathbf{3 d}, \mathbf{3 e}$ and $\mathbf{3 f}$ gave highly inhibition at various concentration, $\mathrm{IC}_{50}=121.6$, $101.9,25.6,29.4$, respectively, than $3 c$ and ST, IC $=234.1,1000<$, respectively. Our results indicated that adding triazine ring to 2- aminobenzimidazole improving its inhibition as antihistamine. The $3 \mathbf{e}$ and 3f compounds give a highly effect as antihistamine in presence of chlorine atom as electron withdrawing group at phenyl nucleus, this inhibition effect may be due to chlorine atom. On the other hand, compound $\mathbf{3 d}$, gives a good effect than $\mathbf{3 b}$, this inhibition may be due to presence of fluorine atom. Therefore, the best inhibition was observed for 3-(4-chlorophenyl) -2-ethyl [1, 2-a] benzimidazolo 
-1, 3, 5-triazin-4-thione (3e). Viswanatha, (2012) ${ }^{33}$ evaluated benzothieno-1,2,3-triazine CP-8, CP-3 and CP-5 and study the antihistaminic activities and found that the chlorpheniramine maleate (CPM), CP-8, CP-3 and CP-5 have exposed a rightward shift in a change of $\mathrm{EC}_{50}$ values in histamine with histamine concentration-response curve (CRC) in all preparations of the four tissue. Also, CPM, CP-8, and CP-5 showed competitive in nature for $\mathrm{H} 1$-receptors as indicated in the slope of the Schild plot. While, it showed non competitive antagonism of CP-3. The CPM, CP-8, CP-3, and CP-5 have shown a mean increase in exposition time against histamine challenge. Also, the anti-inflammatory activities of compounds 1-3, on chose RAW 264.1 cells (inflammatory cells of mice) and INS-1 cells (insulinoma cells of the mouse) were evaluated. The COX-2 level was decreased by $25.41 \%, 14.24 \%$, and $13.06 \%$, respectively, by compounds $3-1$, and the PEG-2 level was decreased by $36.41 \%, 27.05 \%$, and $32.26 \%$ of compounds $3-1$, respectively. The positive control in this study was Ibuprofen and the decrease of COX-2/PEG-2 level is $32.82 \%$ and $42.31 \%$. Generally, all compounds 1-3 in the present study have significant anti-inflammatory activity ${ }^{28}$.

Table 1: $\alpha$-amylase inhibitory of benzimidazolo-1,3,5-triazine derivatives

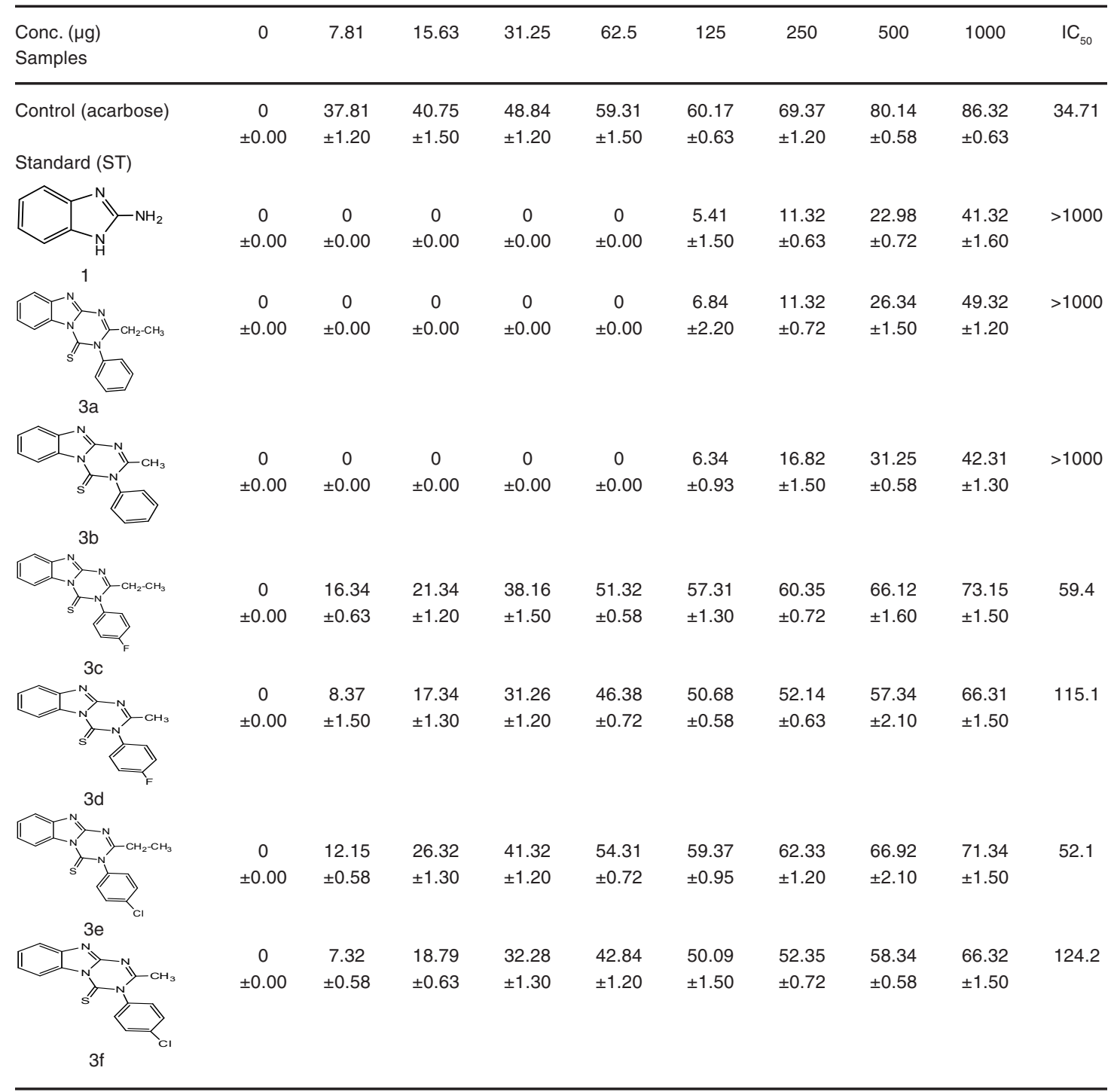

All samples were determined three times and the mean \pm SD used to express the value. The value of IC50 was defined as inhibit $50 \%$ of the concentration activity of enzyme under the assay conditions. 

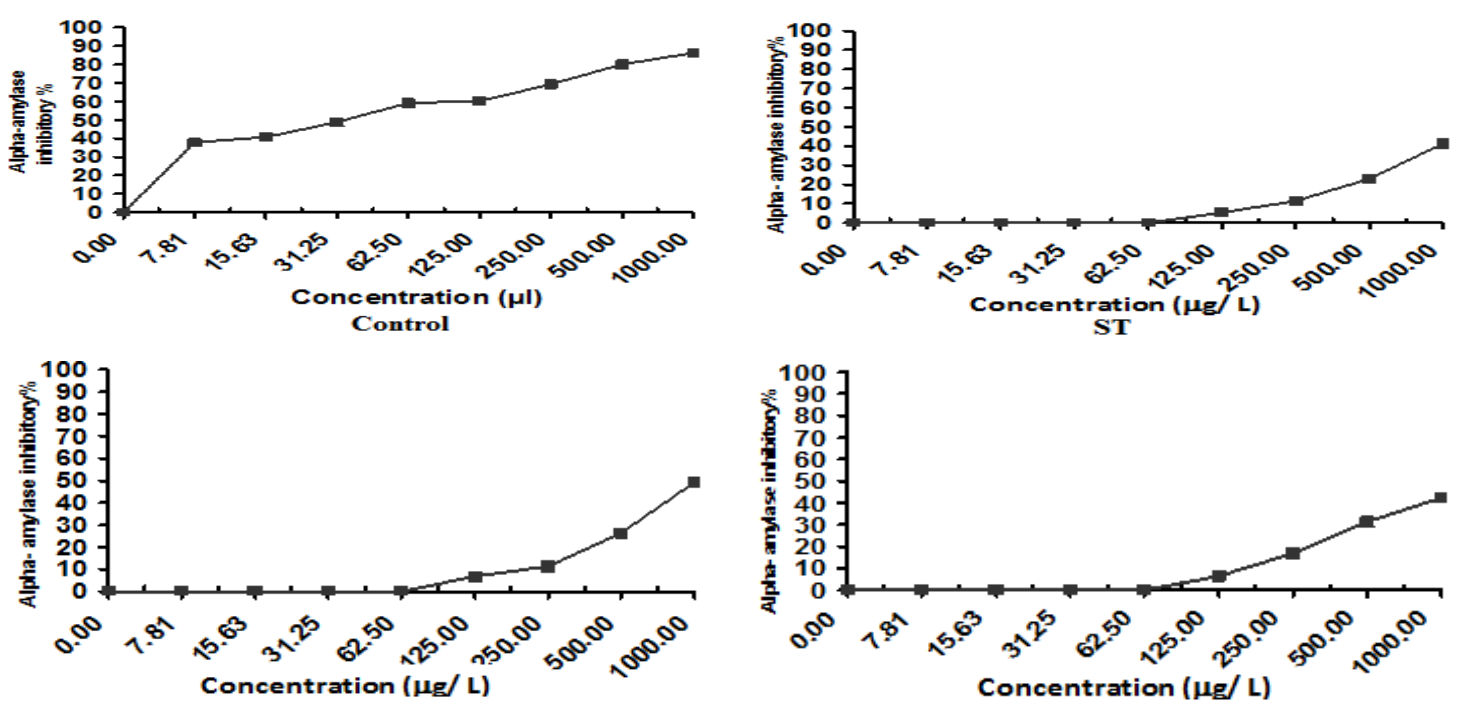

3a

$3 b$

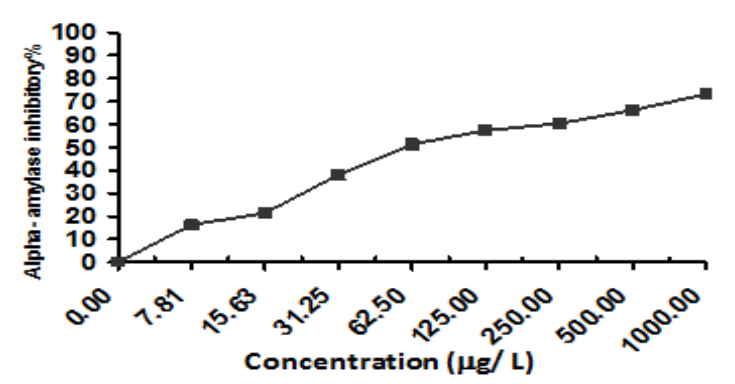

3c

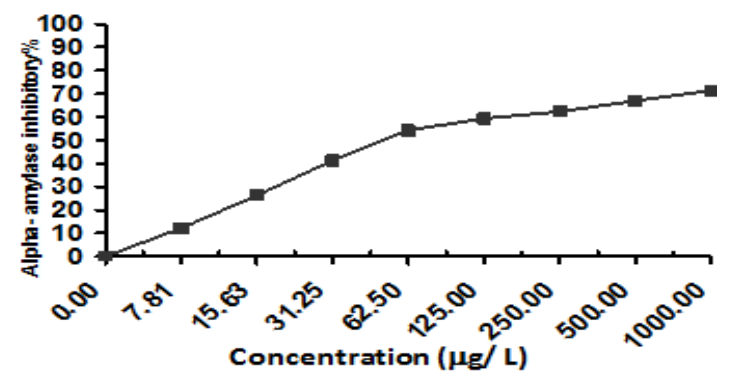

$3 e$

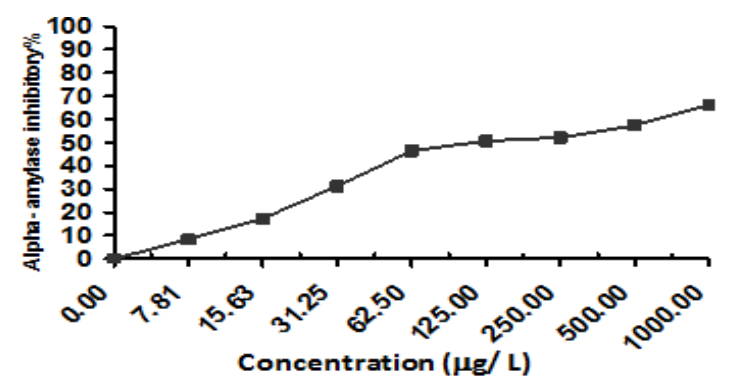

3d

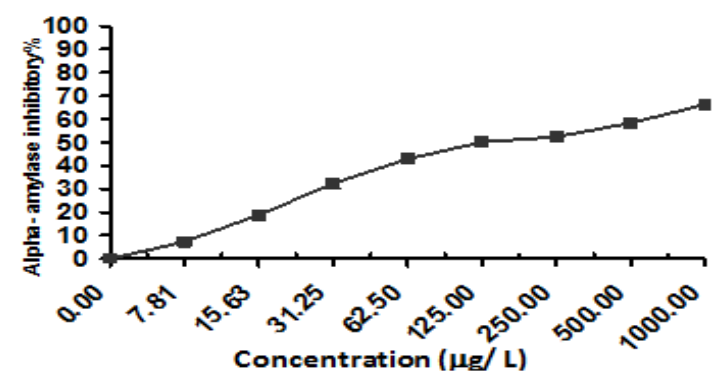

$3 f$

Fig. 1. Effect of $\alpha$-amylase inhibitory on control (acrabose) and newly benzimidazolo-1,3,5-triazine derivatives (3a-3f)

Table 2: Histamine release of benzimidazolo-1,3,5-triazine derivatives

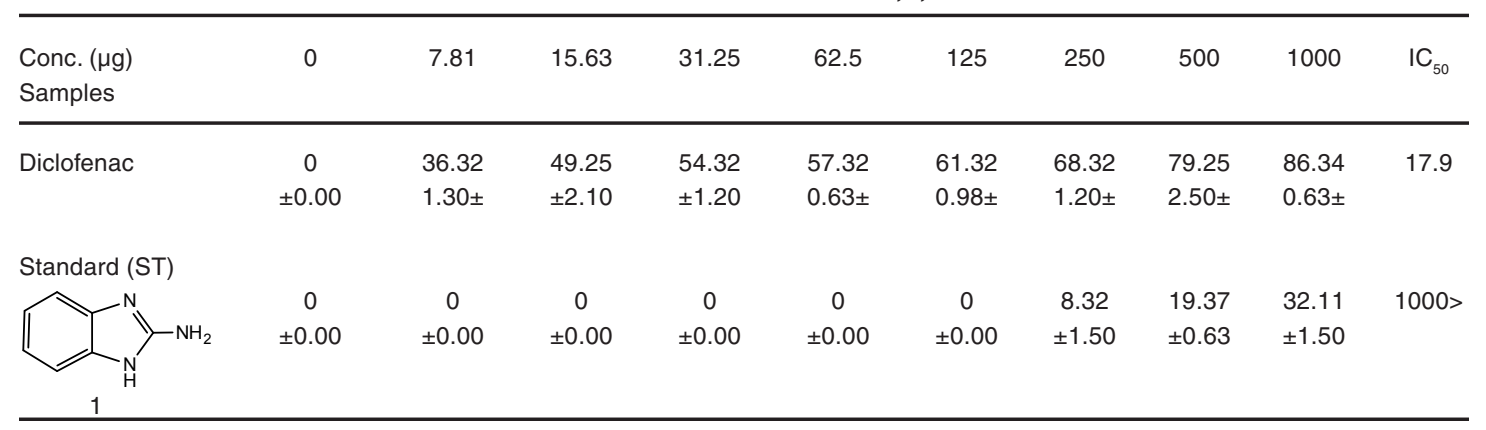




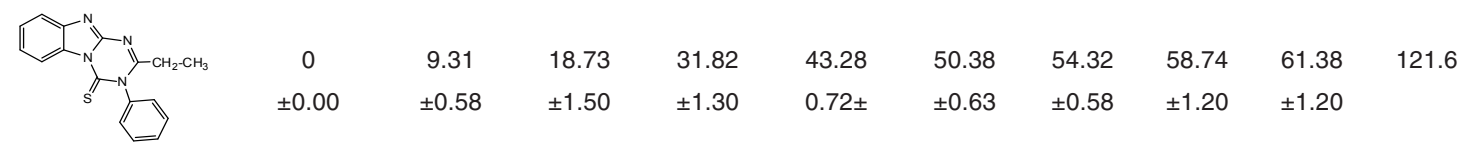<smiles>C/C=C(/C)N1CCN=C2Nc3ccccc3N2C1=S</smiles>

$\begin{array}{ccc}0 & 13.25 & 23.19 \\ \pm 0.00 & \pm 0.72 & \pm 1.50\end{array}$

31.28

41.32

46.38

51.08

54.33

57.32

221.2

$3 b$<smiles>CCC1=NC2=NC3CC=CCC3N2C(=O)C12CCCC2</smiles>
0
\pm 0.00 0
\pm 0.00 0 9.34

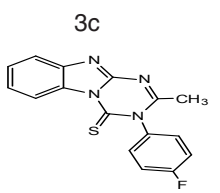

$3 d$

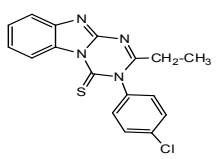

$3 f$

All samples were determined three times and the mean \pm SD used to express the value. The value of IC50 was defined as inhibit $50 \%$ of the concentration activity of enzyme under the assay conditions

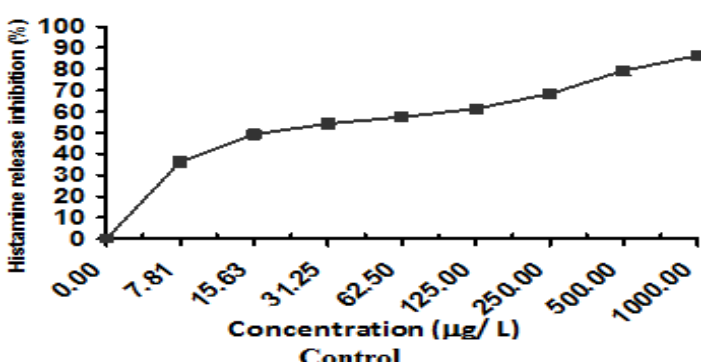

Control

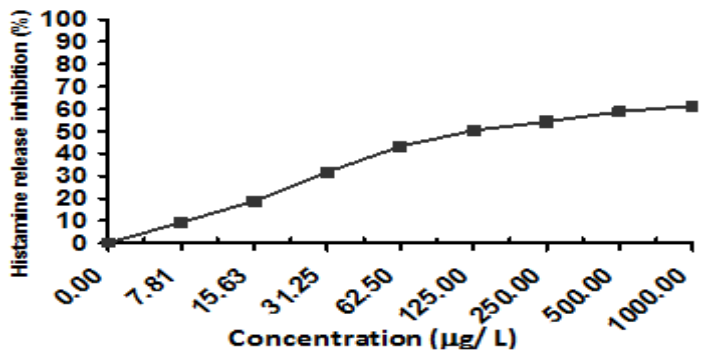

3a

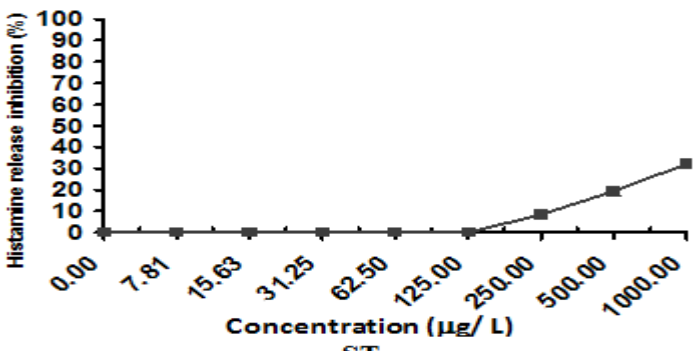

ST

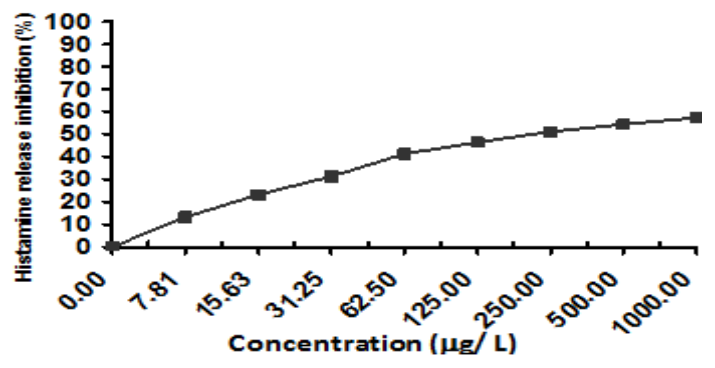

$3 \mathrm{~b}$ 


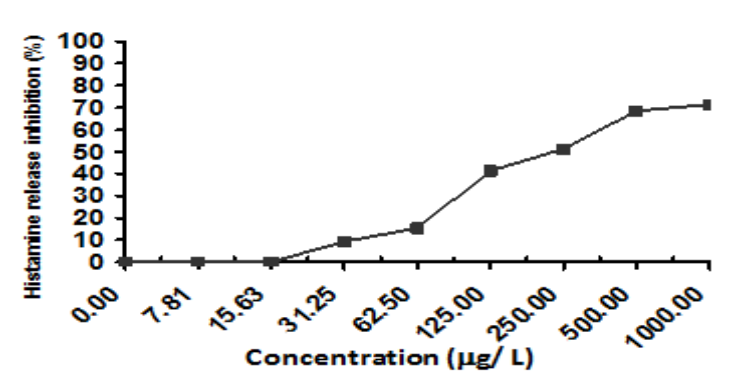

$3 c$

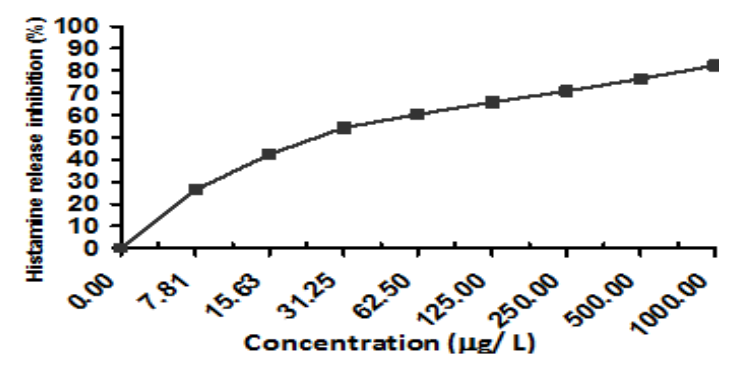

$3 e$

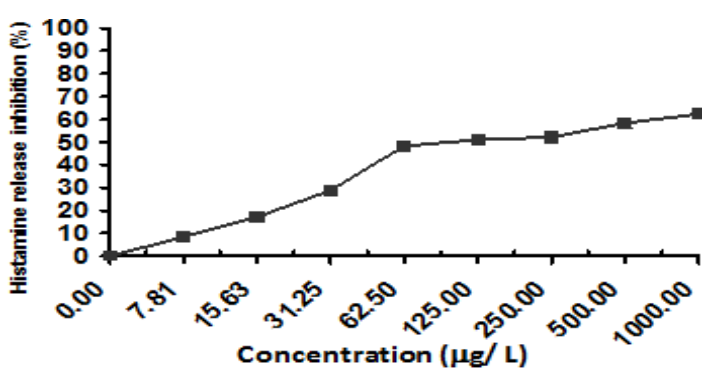

$3 d$

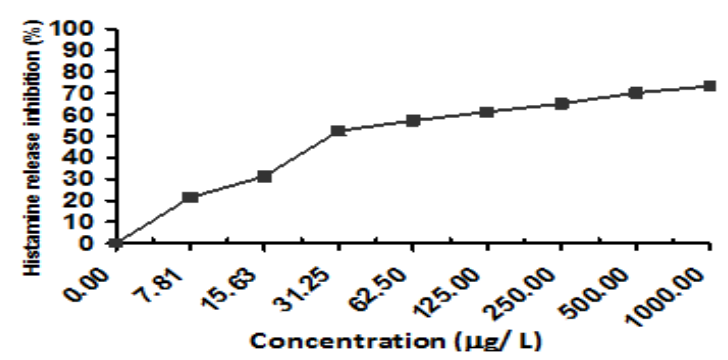

$3 f$

Fig. 2. Histamine release of benzimidazolo-1,3,5-triazine derivatives (3a-3f)

\section{CONCLUSION}

In our study, we have synthesized a novel halogen phenyl benzimidazolo-1,3,5-triazine derivatives from $\mathrm{N}$-(2-benzimidazolyl) imidates, under ultrasound method. The structures were proved by different spectral data ${ }^{1} \mathrm{H} /{ }^{13} \mathrm{C}$ NMR, IR and elemental analysis and Ms. The advantages of ultrasound method in our synthesis, are the short reaction time with enhanced purity and products yields. All derivatives were evaluated for anti-diabetic and anti-histamine activity. Our results had shown interesting biological activity as anti-diabetic and anti-histamine of all derivatives except $\mathbf{3 a}$ and $\mathbf{3 b}$ are inactive as anti-diabetic. The compounds $3 c$ and $3 e$ showed a prominent $\alpha$-amylase inhibition with $\mathrm{IC}_{50}=59.9,52.1$, respectively. On the other hand, compounds $3 e$ and $3 f$ gave a high activity as antihistamine than other compounds.

\section{ACKNOWLEDGMENT}

The authors are grateful for the assistance of King Fahd University of Petroleum and Minerals and Imam Abdulrahman Bin Faisal University.

\section{Conflicts of Interest}

The authors declare no conflict of interest.

\section{REFERENCES}

1. Chavan, R.S.; More, H.N.; and Bhosale, A.V.; Tropical Journal of Pharmaceutical Research, Euro J. Med. Chem., 2011, 10, 463-473.

2. Olga, O.N.; Pihive,E.L.; Maigre, L.; Guinchard, X.; Bouhour, P.; Jolivalt, C.; Schneider, D.; Maurin, M.; Giglione, C.; Meinnel, T.; Paris, J. M.; Denis, j. N.; Bioorg. Med Chem., 2011, 19, 3204-3215.

3. Ahuja, P.; and Siddiqui, N., 2014, 80, 509-522.

4. Kumar A. Int J Pharma Biol Arc., 2011, 2, 744-750.

5. Mhaske, G.; Dighe, S.; Ram, B.; Patil, A.; and Chimbalkar, A. J. Pharm. Sci., 2014, 3, 825-840.

6. Swathi K.; Srinivas A.; and Sarangapani M. J. Chem. Pharm. Res., 2010, 2, 220-225.
7. Patil V.C.; Bhusari, K.P.; and Khedekar, P.B. World J. Pharm. Sci., 2015, 3, 1292-1306.

8. Raghunath, S.A.; and Mathada, K.N. Int. J. Med. Chem., 2014, 12. 1021-1027.

9. Hossain, M.; and Nanda, A. Science Journal of Chemistry., 2018, 6(10), 83-94.

10. Abdel-Rahman, R.M.; Ibrahim, M.A. Ali, T.E. European Journal of Chemistry., 2010, 1, 388-396. http://dx.doi.org/10.5155/eurj chem.1.4.388-396.154

11. Blakley, B., Brousseau, P., Fournier, M. and Voccia, I. Toxicology Industrial Health., 1999, 15, 119-132. http://dx.doi.org/10.1177/074 823379901500110. 
12. Sengupta, A.K., Bajaj, O.P. and Agarwal, K.C. Journal of the Indian Chemical Society., 1980, 57, 1170-1171.

13. Du, Y.M.;Tian, J.; Liao, H.; Bai, C.J.;Yan, X.L. and Liu, G.D. Annals of Botony., 2009, 103, 12391247.http://dx.doi.org/10.1093/aob/mcp 074.

14. Abdel-Rahman, R.M. and Ali, T.E. Monatshefte fur Chemie., 2013, 144, 1243-1252. http:// dx.doi.org/10.1007/s00706-013-0934-6.

15. Makki, M.S.T.; Bakhotmah, D.A.; and AbdelRahman, R.M. International Journal of Organic Chemistry., 2012, 2, 49-55. http:// dx.doi.org/10.4236/ijoc.2012.21009.

16. Makki, M.S.T.; Bakhotmah, D.A.; AbdelRahman, R.M.; and El-Shahawy, M.S.;. International Journal of Organic Chemistry., 2012, 2, 311-320. http://dx.doi.org/10.4236/ ijoc.2012.223043.

17. Abdel-Rahman, R.M.; Makki, M.S.T.; and Bawazir, W.A. E-Journal of Chemistry., 2011, 8, 405-414.

18. Abdel-Rahman, R.M.; Makki, M.S.T.; and Bawazir, W.A. E-Journal of Chemistry., 2010, 7, 593-5102.

19. Welch, J. T.; Eshwarakrishnan, S. Fluorine in Bioorganic Chemistry; Wiley-Interscience Publication., 1991.

20. Kaddachi, M.T.; Hajjem, B.; Baccar, B. J. Soc. Chim. Tunisia., 1988, 2, 17-21.

21. Kammoun, M.; Chihi, A.; Hajjem, B. And Bellassoud, M. Synthetic communication., 2008, 38, 148-153.
22. Kammoun, M.; Kemakhem, M.; Hajjem, B. J. fluorine chem., 2000, 105, 83-86.

23. Ring, J.; Kramer, U.; Shafer, T.; Beherendt, H. Curr. Option Immunol., 2001, 13, 701-708.

24. Larson, A., Fumagalli, F.; DiGennaro, A.; Anderson, M.; Lundbers, J.; Edenitus, C. Br. J. Pharmacol., 2007, 151, 35-44

25. Gatta, F.; Luciani, M.; Palazzo, G. J. Heterocyclic. Chem., 1989, 26, 613-618.

26. Santosh P.C.; Pandeya S.N.; Pathakand A. K.IJRAP., 2011, 2(6), 1726-1737.

27. Zhang, S.L.; Chang, J.J.; Damu, G.; Fang, B.; Zhou, X.D.; Geng, R.X.; Zhou, C.H. Bioorg. Med. Chem. Lett., 2013, 23, 1008-1012.

28. Cao, H.; Liao, S.;Zhong, W.; Xiao, X.;Zhu, J.;Li, W.; Wu, X. and Feng, Y., Molecules., 2017, 22, 1725.

29. Gaba, M.; Gaba, P.; Uppal, D.; Dhingra, N.; Bahia, M.S.; Silakari, O.; and Mohan, C.; Acta Pharmaceutica Sinica B., 2015, 5(4), 337-342.

30. Abdrrahim, R.; Hajjem, B.; Baccar, B. J. Soc. Chim. Tunisia., 1994, 3, 423-426.

31. Ingrid, F.; and Mattias F.M.; Brazilian Journal of Pharmacognosy., 2006, 16(1), 1-5.

32. Venkata, M.; Sripathy R.; Anjana, D.; Somashekara, N., Krishnaraju, A.; Krishanu, S.; Murali M., Rama Verma, S.; and Ramchand, C.N. American journal of infectious diseases., 2012, 8(1), 26-33.

33. Viswanatha, G.L.; Priyadarshini, B.J.; Krishnadas,N.; Janardhanan, S.; Rangappa, S.; and Hanumanthappa, S. Saudi Pharmaceutical Journal., 2012, 20(1), 45-52. 